わゆる局所免疫防御機構の存在が近年ますます注目さ れている。著者らは, 免疫学的立場からの検索が少な かった喉頭に注目し, 成人喉頭を中心に生後のヒト喉 頭での局所免疫機構の存在を報告してきた（第32回本 学会)。本研究では喉頭の局所免疫機椿の発達に焦点を あて, 在胎 3 力月から在胎10力月の胎児15例を対象に 胎児喉頭での腺組織の出現や分泌因子産生能の発現状 況を検索した。腺組織の初期像である glandular bud は 4 力月胎児ですでに観察された。 5 力月胎児以降で は喉頭室を中心に仮声帯, 声带, 声門下の構造が観察さ れるようになり,腺組織の分布も喉頭室, 仮声帯, 声門 下で明瞭に観察された。しかし，その分布様式や分布 密度は生後(特に成人)喉頭とは若干異なり，特に声門 下での腺組織分布では著明であった。局所免疫機構を 検索する目的で著者らは虽光抗体法や酵素抗体法を用 いて IgA や分泌因子の分布を観察した。生後のヒト 喉頭と異なり分泌型 IgA の構成因子である IgA の 分布は認めなかった。一方，他の因子である分泌因子 は 4 力月胎児喉頭内の glandular bud に，すでに観 察された。特に，5 力月以降の胎児では粘膜下腺層の みでなく喉頭内腔を覆う分泌上皮で観察された。

これらの結果から胎生期において, 局所免疫現象で の重要な役割を果たす分泌因子産生能は獾得されてお り, 生後 IgA が供給されるようになって分泌型 IgA として機能することが示唆された。

質問：中島 重徳（近大第 4 内科）

Secretory component は成人気管支組織では, 脉 液腺細胞で産生されているデータを得ているが，胎児 でもそう考えてよいか。

応答：中島格（九大耳鼻科）

胎児でも大部分㢡液腺細胞であり，分泌因子も漿液 腺細胞質からの産生と考える。

㓓問：竹中 洋（京府医大耳鼻科）

局所に存在する免疫グロブリンは局所免疫応答のレ ベルで制御されるものか。

\section{态答：中島格 (九大耳鼻科)}

局所で大部分は制御されていると思う。但し，炎症 等の異なった条件下での全身的免疫機構との関与が考 えられ，今後検付していきたい。

71） マウス肺胞マクロファージのダニ抗原認識過程 に及ぼす影㹕について（第1 報）

○竹中 洋, 星野 章範, 三好 茂 水越 治 (京府医大耳鼻科)

家ダニは I 型アレルギーが主な病因となる鼻アレル ギーや喘息の発症抗原として注目されている。しかし 家ダ二抗原が気道系に吸入されてからの抗原認䧕機構 は十分な解析がなされていない。

今回, 我々は純系マウス C $3 \mathrm{H}$ を用い当教空で考案 したネブライザーを使用し，家ダニ (Dermatophagoides Ferinac）抗原を感作し，この抗原感作マウスの 肺胞マクロファージ(AM)による抗原認識機構の増強 作用について観察した。

実験方法：純系マウス $\mathrm{C} 3 \mathrm{H}$ の雌 6 週10匹をダ二抗 原 $100 \mu \mathrm{g} / 10 \mathrm{ml} \mathrm{PBS}(-)$ で 1 週間間隔で 2 度感作し 2 週 後実験に使用した。実験にはダ二抗原による lymphocyte proliferative response ${ }^{3} \mathrm{H}$-サイミジンの取り
込みによる DNA 合成の定量法を用い, (1)感作マウ ス脾細胞 $2 \times 10^{5}$, (2) 非感作マウス脾細胞 $2 \times 10^{5}$, (3) 感作マウス $\mathrm{AM}$ +非感作マウス脾細胞 $\left(2 \times 10^{8}+2 \times\right.$ $10^{5}(1: 100)$ の 3 群にて 比較検討した。なお, 培養 には $10 \%$ FICS 加 RPMI 1640 を用い， $37^{\circ} \mathrm{C}, 5 \% \mathrm{CO}_{2}$ 下に 5 日間行った。

結果：感作マウス脾細胞はダニ抗原非添加群では, 269CPM であったが $0,156,0,625,2.5,10 \mu \mathrm{g}$ と抗 原量を増加すると, DNA 合成も増加し $10 \mu \mathrm{g}$ 添加群 では $2842 \mathrm{CPM}$ と10倍以上の値を示した。一方非感作 マウス脾細胞群では全ての抗原莨度で有意な刺激定数 を認めなかった（SI<2.35)。これに感作マウス AM を加えた群では, $10 \mu \mathrm{g}$ 抗原加群にて 3036CPM と非添 加群に比し15倍以上の刺激定数を得た。またこの值は MLR による補正を行うと刺激定数でも十分な回復を 示した。ついでAM 免疫組織化学的性格を報告した。

考按：ダ二抗原で感作されたマウスAMは L.P.Rを 増強し明らかに抗原認識に関与していることが判明し た。

篗問 : 中島格 (九大耳番科)

感作にどうして吸入抗原をえらんだか。

応答：竹中 洋 (京府医大耳鼻科)

気道系の免疫応答に関与寸る細胞群の相互関与を観 察するために吸入感作を選んた。しかし感作抗原量の 一定化に問題がありこの点に留意し実験を続けたい。

72）マウスの気道系インターフェロン産生ーインフ ルエンザ感染についてー

○星野 章範, 三好 茂, 竹中 洋 斎藤 等, 水越 治

(京府医大耳鼻科)

ウイルス感染症が疑われる急性上気道炎の患者の鼻 汁中にインターフェロン (IFN) 活性が測定されるこ とをすでに報告したが，今回その動物実験モデルとし てマウスのインフルエンザ感染症における IFN 産生 と肺内ウイルス，増殖の動態について報告する。まず 5 週龄の䧳の $\mathrm{C} 3 \mathrm{H}$ マウスをインフルエンザ $\mathrm{A}$ 型ウイ ルス（PR8）を用いてネブライザーで感染させ, ウイ ルスの $\mathrm{LD}_{50}$ を算出した。以降これで得られた一定の ウイルス量 $\left(1 / 2 L_{50}\right)$ で均一に多数のマウスを感染 させ, 日を追ってマウスを殺し，血清，気道洗浄液中 の IFN 活性及び肺ホモジネート中のウイルス量を測 定した。また産生される IFN を $\mathrm{pH} 2$ 処理及び抗ネ ズミIFN 血清による中和実験で調べた。IFNの定量 には $\mathrm{L}_{929}$ 細胞一VSV (vesicular stomatitis virus) 系の CPE 法, インフルエンザウイルスの定量はイヌ 腎蔵由来の MDCK 細胞を用いた CPE 法で行った。 結果, 肺内ウイルス量は感染後 1 日目から上昇し第 3 日目にピークを示す。これに対し気道洗浄液中の IFN はウイルスの增加を追って上昇しやはり第 3 日目に数 百単位 $/ \mathrm{ml}$ に達し, ウイルスの増殖を抑さえるように して減少し第12病日以降には测定限界以下となる。ま た血清中の IFN も気道洗浄液中のそれと同様のカー ブを描いた。一方ウイルス特異抗体はこれにおくれ第 6 病日以降にならないと上昇しない。産生されたIFN は $\mathrm{pH} 2$ で安定で抗ネズミ IFN 血清で中和された。 これらのことより, 気道洗浄中の IFN は, ウイルス 
感染初期の生体防御に重要な役割を果していることが 裏つけられた。

質問：杉山 正夫 (阪大耳番科)

(1)気道系の局所で IFN を産生しているのはどの細 胞と考えるか。

(2)IFN と virus 抗体価については祱明のような 1 つのパターンがあると思らが，virus 産生については， 全例が 1 つのパターンを取るのではなく，個体差によ る変動はなかったか。

応答：星野 章範 (京府医大耳鼻科)

(1)産生された IFN は, $\mathrm{pH} 2$ で安定で $\mathrm{C}_{248}$ - NDV (Newcastle Disease Virus) 誘発 IFN に対する抗 体で完全に中和されることより, 非 $\gamma$ 型で $\alpha$ 型及び $\beta$ 型の混合 IFN であると思われる。また IFN 産生細 胞の研究は今後の重要な問題である。(2)ウイルスの增 殖が頭打ちになる第 3 病日で, ウイルス特異的抗体は 出現せず，IFNの抗ウイルス作用と補体，NK 細胞な どの他の非特異的生体防御機構の関与も考えられる。

\section{第14群 基䃈一 3 \\ 座長 平野 実 (久大耳鼻科) \\ 73）各内哄頭筋の協調収縮による声門運動の分析 ○传藤 文彦, 竹之内 智, 鈴木 由一 矢野原邦生, 久 育男, 日向 誠 （京府医大耳鼻科）}

喉頭機能の主役である声門運動は, 内喉頭筋の単一 收縮によって形成されることより,これらの協調収縮 によって形成されることの方が多い。この内喉頭筋の 協調収縮による声門運動の分析をすすめるには各内喉 頭筋の性格とその収縮によって形成される声門運動を 調へてておく必要がある。そこで雑種成犬を用いて神経 刺敫による内唉頭筋收縮時の声門圧, 声門幅, 開閉張 力, 声帯長径の殊に刺激頻度の変化に伴ら変動を測定 し収縮特性と対比した。

1) 前筋収縮時：各測定值と収縮特性のうちの融合 頻度を対比させてみると，全ての測定值が $35 \sim 40 \mathrm{~Hz}$ で最高かっ一定になり，これは筋自体の融合頻度 $40 \mathrm{~Hz}$ と一致する。

2）声帯笳収縮時：声門開閉運動を示す閉鎖張力, 声門幅は $60 \sim 70 \mathrm{~Hz}$ で頭打ちとなるが，声門閉鎖圧， 声帯長径は $90 \sim 100 \mathrm{~Hz}$ まで増強又は短縮する。この筋 肉の融合頻度は $95 \mathrm{~Hz}$ で，開閉運動に対しては，かな りの余裕を残している。

3）後笳収縮時：測定法の性格上，声門圧の測定は できなかったが, $40 \sim 45 \mathrm{~Hz}$ で声門開大張力, 声門幅 が最高となり,これ以上頻度を増しても変化はない。 なお，この筋の融合頻度は $45 \mathrm{~Hz}$ である。

4) 側筋収縮時：側筋の融合頻度は $90 \mathrm{~Hz}$ であるが, 声閏幅は $60 \mathrm{~Hz}$ で完全開鎖し，開鎖張力は $40 \mathrm{~Hz}$ より更 に徐々に增加し, $80 \sim 90 \mathrm{~Hz}$ で最高となる。この声門 閉鎖に対する余力は，代償性声門閉鎖との関連性を示 唆する。

5）反回神経刺激時：刺激頻度を増していくと，ま ボ，融合頻度の早、後筋の影響で声門が開大し，20 $25 \mathrm{~Hz}$ より徐々に閉鎖筋群の力が增すにしたがって閉 鎖方向に進み，声門圧も増加するという現象が，各内
喉頭筋の特性から理解できる。

74）㖓下時の喉頭運動の解析

○古川 浩三, 西端 慎一, 鈴木 徹 斎藤彰, 池上 彰博, 代田 正道 新美 成二, 設楽 哲也 (北里大耳鼻科)

喘下第 2 相は, 生理学的には反射運動期と定義さ れ，1 般には bolus の先端が口狭を越えて咽頭内に 入ってきた時点を第 2 相の始まり, 後端が食道に入っ てきた時点を第 2 相の終りとしている。我々はこの第 2 相の定義より喉頭運動における睘下第 2 相について 検討した。方法は頚部側面より $\mathrm{Ba}$ の藏下時にX線シ ネ撮影を施行し, フィルムモーションアナライザーに よって喉頭の挙上運動と $\mathrm{Ba}$ の移動を同時に測定し た。撮影速度は, 種々について検討したが, 30コマ/ /sec. で充分な情報が得られることが判明したためこ の速度を使用した。

買下による喉頭の挙上運動は, 緩徐相と急速相の二 成分にわかれ，緩徐相の時間は加龄により延長した。 急速相の時間は加齢による変化はなかった。嬹下第 2 相の時間は平均 0.5 秒で, これには加齢による変化は 認められなかった。魦下により喉頭挙上に要する時間 は，加齡により延長し，それに伴って，第 2 相の開始 時点は遅れた。しかし, 最大挙上位置から逆に開始時 点を検討したところ, 平均 0.30 秒でほぼ一定であっ た。この第 2 相の開始時点は, 喉頭の挙上運動の中で 急速相であり, 喉頭運動から第 2 相を定義すると, 急 速相の開始時点から下降運動の開始時点までとするこ とが妥当と思われた。

追加：新美 成二 (北里大耳鼻科)

運動解析に映画を用いるが，撮影速度は対象とする 運動スピードとのかねあいで決定しなくてはならな い100コマで撮影し解析した 結果, 躏下運動には 30 コマで充分な情報が得られることが明らかとなった。

質問：棚橋 汀路 (名大分院耳糗科)

喉頭急上昇期を第 2 期開始とすると, 私の分析では 正常例全例中咽頭に入っている。異常例では先生のよ 5に bolus と喉頭の位置関係がある例を経験してい るが。

応答：古川 浩三（北里大耳鼻科）

喉頭が急速に举上するその開始の時期には, まだ bolus は口腔内である。喉頭の前方への移動開始時点 よりも第 2 相の開始は前日始をる。

\section{質問：進 武幹（佐賀医大耳鼻科）}

反射期を㗆下 2 期とすることは異論はないが，反射 期のみをとらえてみると, 喉頭挙上はこの時期におこ っているので, 演者のいう喉頭運動の開始は第 2 期で はないのか。

応答 : 古川 浩三

曣下第 1 相でも喉頭の挙上運動は急速に挙上する反 射期に入っているといら結果になった。この第 1 相, 第 2 相とい5分類は bolus の動熊からみた 分類であ る。

75）喉頭挙上および下降に関与する筋の運動性ノイ ロンについてーHRP 法によるー

○宮崎 俊巳, 吉田 義一, 平野 実 (久大耳鼾科) 


\section{進武幹（佐賀医大耳鼻科）}

金関 毅 (九大第 3 解剖)

喉頭の挙上および下降に関与する筋の運動性ノイロ ンの局在を HRP 法を用いて追究したので報告する。 研究対象にはネコを用い検索を行った筋は, 頭二腹筋 (前腹並に後腹)，䂭舌胃筋，オトガイ舌骨筋，甲状舌 骨筋，胸骨舌骨筋，胸骨・甲状筋の 7 筋である。

成績 颛二腹筋前腹注入例：標識細胞は三叉神経運 動核内のみに認められ，核内においては背内側部に位 置していた。額二腹筋後腹注入例：標識細胞はいわゆ る副顔面神経核に出現した。顎舌骨筋注入例：標識細 胞は三叉神経運動核内のみに存在し，核内に抢いては 腹内側部に局在していた。オトガイ舌骨筋注入例 : 標 識細胞は舌下神経核内のみに認められ，核内では最も 腹側に位置していた。また吻尾方向においては舌下神 経核の吻側部約 $2 / 8$ 亿存在していた。甲状舌骨筋注入例 : 標識細胞は舌下神経核および $\mathrm{C}_{1}$ の前角内に認められ 舌下神経核内においては外側部に， $C_{1}$ の前角内におい ては背内側部に位置していた。標識細胞柱は吻尾方向 で舌下神経核の尾側部約 $1 / 8$ おび $\mathrm{C}_{1}$ の前角吻側部約 $1 / 2$ にわたって存在した。胸骨舌骨筋注入例：標識細胞は 錐体交叉の吻側端より出現し， $\mathrm{C}_{1}$ を経て, $\mathrm{C}_{2}$ の前角細 胞にまで及んでいた。 $\mathrm{C}_{1}$ おひび $\mathrm{C}_{2}$ の前角内においては ほぼ中央部に認められた。胸骨甲状筋注入例：標識細 胞は胸骨舌骨笳のものよりもやや尾側より出現し, $C_{1}$ およびC $C_{2}$ の前角細胞に存在していた。前角内において はほぼ中央部を占めていたが胸骨舌骨筋のものよりも 腹外側に出現する傾向がみられた。

今回の研究で同じ舌骨上筋群に属しながらその支配 運動性ノイロンの核の違い，また，同じ舌骨下筋群で むるのに逆の機能をもつ筋の運動性ノイロンの局在の 差違が明らかとなった。これらの結果は喉頭の機能を 支配する中枢機序の解明に奇与するものと思われる。 研究方法は予稿集に記載したので割愛する。なお, 買 二腹筋 (前腹並に後腹), 瀕舌骨筋の追加を行った。

質問：久 䢛男 (京府医大耳畺科)

胸骨舌根筋のような比較的大きい筋肉への注入につ いて何か留意されている点があるか。

応答：宮崎 俊巳 (久大耳鼻科)

内喉頭筋の 場 合, HRP 注入量は $1 \mu \mathrm{l}$, 舌骨下筋群 等のやや大きめの筋肉の場合, $2 \sim 3 \mu 1$ で，注入場 所 は筋腹ほぼ中央 1 力所のみ注入している。

76）両側反回神経の吻合枝について

○李 同海, 飯塚 俊勝, 荒井 潤 林 永直, 沖倉一彰, 今野 董夫 遠藤师り(東医大耳畺科)

上・下喉頭神経の喉頭内における分布状態をより明 確にしようといら考えから，両側反回神経の吻合枝に ついて究明した。

研究材料は, 約 $8 \mathrm{~kg}$ から $15 \mathrm{~kg}$ の 7 頭で, 摘出した 喉頭を $10 \%$ ホルマリン液で固定したあと水の中に入れ て軟部組織を剥離し易いようにした。軟部組織の剝離 は肉眼的及び拡大鏡下で行った。発見した吻合枝はそ の分布位から考えて知覚性と思われるものが 7 頭の中 2 頭，また運動性を思われるものが 7 頭の中 7 頭全部 に認められた。発見した吻合枝は全例組織学的に確認
しその組織学的所見と吻合枝そのものの写真を合成ス ライドにして発表した。

知覚性と考えられる吻合枝は両側のガレンの吻合か ら出ていて䩱状軟骨後面の上縁で吻合を形成してい る。運動性と考えられる吻合枝は両側の横筋枝が横筋 に進入する直前で 2 分枝に分れる中の 1 枝で横筋の下 部で反対側の横筋枝と吻合を形成している。

この 2 本の吻合枝について内・外の耳鼻咽喉科学, 及び解剖学の文献にもその記載がなく昔から云われて きた，横筋の両側支配は左右の反回神経加横筋枝を 出しているだけでなくこの吻合枝が大いに関与してい るものと考える。この吻合枝の発見によって現在知ら れている喉頭内に括ける末梢神経の分布状態はまだ不 完全でありそれをより明確にする事が必要である。

また，上・下喉頭神経の喉頭内における各分枝の名 称が各研究者によってそれぞれ異なるものがあり，そ の名称を統一することが必要であると考える。

質問：進 武幹（佐賀医大耳鼻科）

1）犬の喉頭神経の走行は多種多様と思われるが。

2）生理実験の結果の解釈につながるので, 両側の 吻合枝などの機能は運動枝と考えているのか。

\section{忘答：李 同海 (東医大耳鼻科)}

1）例えば知営性の吻合枝が 7 頭の中 2 頭だけ発見 できたから 5 頭が正常で，2頭が奇型とはいえない。 むしろ 5 頭については発見できなかったものと考えて いる。

2）運動性の吻合枝は，バイパス的な役割をするの ではないかと考えている。

質問：久 育男 (京府医大耳礐科)

吻合枝における線維構成（特に無髄神経線維が含ま れていたか否か)について調べているか。

応答：李 同海

今回は吻合枝を発見するために，それ以外の線維構 成については割愛した。

77）犬内啹頭筋支配運動神経細胞の局在一蛍光色素 による逆行性軸索輸送法を用いて一

○久 育男, 松井 隆史, 佐藤 文彦 日向 誠, 竹之内 智

（京府医大耳劓科）

最近, 種々の蛍光色素を用いた逆行性軸索輸送法に よる neuron 標識が多くの領域で使われている。本法 では, 同一個体で二重, 三重標識が可能となる。今回 我々は, 各種の蛍光色素をもちい, 犬の輪状甲状筋, 後輪状披裂筇, 甲状披裂筋を支配する運動神経細胞の 起始核を検索した。

雑種犬の各筋を Ketamine $(30 \mathrm{mg} / \mathrm{kg}$ im) 麻酔下に て明視下におき，同一犬の輪状甲状笳には propidium iodide (PI) (2.5\%: 蒸留水), 後輪状披裂筋には 4, 6-diamidino-2-phenylindole (DAPI) (2.5\%蒸留 水), 甲状披裂筋には primuline(p) (10\%: 苲留水)

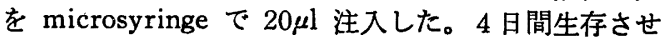
$4 \%$ paraformaldehyde $+0.5 \%$ glutaraldehyde(PBS) にて経心臓的に灌流固定し脳幹を摘出した。試料は同 固定液にて一夜後固定したのち，15\% sucrose (PBS) に一冝夜浸漬した。Freezing microtome にて脑幹下 部の連続切片 $(40 \mu \mathrm{m})$ を作成し封入後蛍光顕微鏡にて 
検鏡，標樴細胞を撮影した。その後切片に $0.3 \%$ Carbol-Thionin 染色を行い蛍光顕微鏡写真と照 合し た。

虽光を有した標識細胞は同側の疑核にのみ観察され た。PI による赤い蛍光を有した細胞は顔面神経核直 下より尾側に延びており，吻側端では核内内腹側部に 存在した。赤い細胞群の尾側端からより尾側より, DAPI による青い細胞群, $\mathrm{p}$ による黄色い細胞群が形 成され, obex より尾側迄存在した。青細胞群と黄色 い細胞群との核内レベルの差は最大 $400 \mu \mathrm{m}$ であった。 また, 核内で前者は腹側にやや散在して後者は背側に やや集まって存在した。標識細胞群は前筋支配のもの が最も吻側に存在し続いて後筋は内笳の順であるが後 筋は内筋に関してほぼ同レベルであった。また前筋支 配細胞群は疑核吻側端では腹側部に存在し，内筋，後 筋は支配細胞群は obex を中心として前者は腹側に やや集まり，後者は背側にやや散在して認められた。

質問：吉田 義一 (久大耳畺科)

色素の注入量が増える時は拡散防止にいかなる法を とっているか。

応答：久 育男 (京府医大耳舅科)

注入量の問題は現在減量がかなり可能となってお り，今後なお一層確実にするよう努力したい。

78）気道肺疾患の気道反応性に対するリドカイン前 吸入の抑制効果

○大石 光雄, 高木 洋, 山崎 公世

上西 豊基, 藤本 知久, 川崎美栄子

津谷 泰夫, 中島 重徳 (近大第 4 内科)

目的：気道過敏性の充進は機能的気管支攣縮発症の 重要な因子であるが，その実態はなお不明で，とくに irritant receptor その他の receptor との関係は十分 明らかではない。われわれは 1 秒量を指標とした気道 過敏性について報告したが加えて Astograph による 気道反応を検討し今回はリドカイン吸入による気道粘 膜麻酔の気道反応に及ぼす影響を検討した。

方法：対象は15 66歳の健常者 6 例，気管支嚾息13 例，鼻アレルギー 4 例その他慢性気管支炎，慢性肺気 腫，アレルギー性気管支炎，急性気管支炎など合計 32 例である。

測定は CHEST 社製 Astograph を用い $3 \mathrm{~Hz}$, Oscillation 法で各例について $4 \%$ リドカイン前吸入 前処直時と末処置時の塩化メサコリン吸入負荷による 呼吸抵抗の変化を連続的に測定し, Rrs·cont, C min, St, Sr および Rrs·e の 5 つの指標を算定し比較し た。

結果：1）健常非喫洷者は,メサコリン $25 \mathrm{mg} / \mathrm{ml}$ ま での吸入で気道反応に変化をみず, リドカイン前処置 でも影響されす，健常喫煙者はリドカイン前処置によ り初期抵抗の減少傾向, 反応閏值の増加傾向および反 応度の明らかな減少をみとめた。2）喘息ではリドカ イン前処置により反応閶值, 反応度とも増加するも の, 堿少するものがみられ. また喫煙の影響は一定の傾 向を示さなかった。3）喘息の反応闒値はその基準値 が低值のものはリドカイン前処置で増加し, 基淮值が 高値のものは減少する傾向を示した。4）リドカイン 前処置で鼻アレルギーの反応闒值は増加傾向を示した
が，初期抵抗や反応度はさまざまで他の気道肺疾患で は 3 指標とも，一定の傾向がみられなかった。

結論：リドカイン前吸入によって，メサコリン吸入 による気道の過敏性と反応性に対する作用の差異が示 唆された。

\section{第15群 基礎一 4 \\ 座長 戸川 清 (秋大耳鼻科)}

79）粘液線毛輸送能に及ぼす気道粘液の影率

○間島 雄一, 坂倉 康夫, 松原隆 村井須美子, 堀 みどり, 三吉 康郎 (三重大耳鼻科)

気道の局所防呩機構の一主要因子と考えられる粘液 線毛輸送機能には線毛と粘液層との相互作用が重要な 役割を演じている。食用ガエルロ蓋を摘出し, $25^{\circ} \mathrm{C}$ 湿度 $100 \%$ で 36 時間放置すると口蓋粘液分泌はもはや認め られず線毛のみが活発に動く線毛モデルを得ることが できる。このカエルロ蓋線毛モデルを用い粘液の性状 及び量が粘液線毛輸送能に及ほす影響を検討した。

副鼻腔炎患者鼻汁を凍結乾燥して得た粉末鼻汁を生 理的食塩水に溶解して作成した $4 \%$ 再生鼻汁 1，2， 4, $8 \mu 1$ はカエル口蓋線毛モデルで同様の粘液線毛輸 送能を示した。また，10\%再生鼻汁 $1,2 ， 4,8,12$ ， $15 \mu \mathrm{l}$ 粘液の量に関係なく同様の粘液線毛輸送能を示し た。粘液の量は $4 \%$ 再生鼻汁で1 $8 \mu 1 ， 10 \%$ 再生鼻汁 で 1〜15 $\mu \mathrm{l}$ の間では粘液線毛輸送能に影響を収ぼさな いことが示された。

粘液の性状が粘液線毛輸送能に及ぼす影響を知るた め2.5, $5,10,12,15,20 \%$ の再生鼻汁 $2 \mu 1$ をカエル の口蓋線毛モデルに用い，その粘液線毛輸送能を測定 した。2.5，5\%再生鼻汁が 最も速い粘液線毛輸送能 を示し, 鼻汁濃度が上昇するに従い輸送能は減少し た。20\%再生鼾汁では粘液線毛輸送は認められなかっ た。重力の粘液線毛輸送能に及ぼす影響をみるため口 蓋線毛モテルを傾けて $45^{\circ}$ と $90^{\circ}$ の勾配負荷をかけ， $0.5,2.5,4,15 \%$ の再生番汁 $2 \mu l$ を口蓋モデル下端 に执き,これらの粘液が重力に逆って上端に輸送され る速度を測定した。2.5，4，15\%再生番汁は $45^{\circ}, 90^{\circ}$ の勾配負荷により粘液線毛輸送能は低下したが認めら れた。一方, $0.5 \%$ 再生鼻汁では $45^{\circ}$ の勾配負荷で極端 な粘液線毛輸送能の低下を認め, $90^{\circ}$ の勾配負荷では 粘液線毛輸送は認められなかった。以上より粘液線毛 輸送能は粘液の濃度により変化し，有効な粘液線毛輸 送能は最適の粘液濃度により得られることが示唆され た。

\section{質問：戸川 清（秋大耳鼻科）}

再生鼻汁の $2.5 \%, 5 \%$ で線毛機能が最もよかったと いうことは, 正常鼻汁中の固形成分はその位の濃度と 考えてよいか。

応答：間島 雄一 (三重大耳鼻科)

鼾汁の粘弾性を比较すればどの濃度の再生鼻汁が生 理的鼻汁に一致するのか明らかにできるが両者の比較 はしていない。

80）気管線毛に対するレーザー光線の影噌（二報）

○高山 乙彦, 内田 実, 水島 則夫 竹田 幹男, 角田真一郎, 冨田寛 
(日大板橋病院気食科)

レーザー光線の気食線毛に対する影響について前回 は成犬を用いた成績を発表した。

今回はヒト気管線毛に対する $\mathrm{CO}_{2}$ レーザー, YAG レーザーの影響について観察し両者の比較検砷を行っ た。ヒト気管は気管に病樫波給していない喉頭癌の摘 出手術寸前のものを対象とし，術前放射線照射の波給 していない気管第2欶骨部粘膜にレーザーを照射した。 レーザー照射量は両者とも10Joulesとした。 $\mathrm{CO}_{2}$ レーザーでは光顕では crater 辺縁は鋭利であ った。YAGでは光顕では，組織のVaporization を来 し, 辺縁は不規則であり, $\mathrm{CO}_{2}$ より粘膜表面の影響範 囲は広いように思われた。走査電顕では, $\mathrm{CO}_{2}$ は光顕 を裹つける所見を呈し, crater 辺縁は非照射部位と 明瞭な境界を示していた。強廓大すると crater内の組 織は融解を示し,また辺縁の線毛にも融解が見られ た。しかし周囲への影響筈囲は狭い上らであった。線 毛への影響範囲は境界がかなり明膫に区別できた。 YAG では, crater 周辺の線毛一の影響範囲はやや広 いよらであった。しかし $\mathrm{CO}_{2}$ に比べて不規則な傾向 が見られた。crater 内面は蜂の巣のごとき穿孔がなら び，あるいは融合しているところも見られた。周囲の 線毛への影響範囲は境界がかなり不規則であることを 示していた。

以上からヒ卜気管粘膜への影響は，前回発表した成 犬で見られた所見と殆ど同様のものであり，また $\mathrm{CO}_{2}$ と YAG との比較も成犬気管粘膜の場合と類似してい た。気管線毛に対する影響も両者とも殆ど同様のもの であった。

質問 : 戸川 清 (秋大耳鼾科)

レーザー照射後の粘膜の障害回復過程はどうか。

态答：高山 乙彦 (日大板橋病院気食科)

$\mathrm{CO}_{2}$ レーザーと YAG レーザーは組織に対する影響 が異なるので治瘾機転を比較することは困難であるが $\mathrm{CO}_{2}$ レーザーの方が幾分早く治るように思う。

81）気管粘液線毛運動の光電変換法による in vivo の測定一薬物効果の判定への応用一

○坂本 邦彦, 橋本 真実, 清田 隆二 大山 勝（鹿大耳鼻科）

满井 一敏（慶大伊勢病院ME科）

モルモット気管粘膜の粘液線毛運動に対する薬物の

影響を, 光電変換法を用いて検尉し，その結果を報告 した。

方法：本法は，粘液線毛機能を臨床的に簡便に把握 すべく開発したもので，手術用䡩微鏡下の反射光変動 を電気的に変換するものである。実験にはモルモット を用い, ネンブタール深麻酔下に気管粘膜を露出さ せ, 温度 $32^{\circ} \mathrm{C}$, 湿度約 $100 \%$ に設定した恒温槽内にて 記録した。記録波形は，経時的な波数の変化およびパ ワースペクトラム分析により検討を加えた。用いた薬 版は，塩化リゾチーム，プレドニゾロン，サルブタモ 一ル硫酸塩, 硫酸オルシプナリン, チロキサポールの 5 種類，コントロールとしての生食水および $2 \%$ 塩酸 リドカインである。

結果ならびに考案：(1リドカインでは滴下後線毛運 動波数の有意な低下を示すが，経時的に回復する。(2)
リゾチーム, プレドニゾロンの 2 群は有意の変化は認 めなかったが, 後者に波数の低下傾向が示された。(3) サルブタモール, チロキサポールの 2 群で, 滴下後, 線毛運動波数の有意な賦活傾向を示した。(4)サルブタ モール，オルシプレナリン，チロキサポールの 3 群 で, 波形の規則性が上昇した。リゾチームでは粘液層 の溶解流出像が顕微鏡下に観察され正常粘液線毛系に 影響した可能性もある。今後, 病態モデルでの検討を 加えたい。サルブタモールとオルシプナリンは $\beta_{2}$-stimulant であるが，両者とむに低 $\mathrm{pH}$ でありながら抑 制作用は認められず，それを上回る強力な賦活作用を 有することが示唆された。また, チロキサポールは界 面活性剂であり, 粘液層が線毛運動にとって良好な条 件へ変化したと考えるのが妥当であろう。

以上の如く, 本法の粘液線毛運動観察法としての有 用性が示され, 臨床応用への妥当性が確認された。

質問：間島 雄一（三重大耳鼻科）

気管粘液線毛運動と粘液線毛輸送速度との間に相関 はあるのか。

応答：坂本 邦彦（鹿大耳兽科）

薬物滴下により，波数の変化が起こるが，これと輸 送能の関係は平行して同時に検討すべきである。波数 が上昇したからといって輸送能が上昇しているとはい えず, 粘性の問題が関与してくると思う。

82）花粉中有機酸の気道粘膜に及ぼす影響

○大迫 茂人 （大阪市立小児保健センター耳鼻科）

大橋 淑宏, 村岡 道徳, 季 起栄 中井 義明 (阪市大耳鼻科)

研究目的：花粉症の発生には抗原抗体反応以外に花 粉と他の抗原との間の成分上の差による影響や花粉の 上気道各部位への影響の差などの因子が関与している と考えられる。

その因子の $1 つ と し て ， 1977$ 年大本らによって報告 された花粉中有機酸に着目した。9 種類も存在する有 機酸中より蟻酸と酢酸を選び, その混合液の上気道粘 膜に及ぼす影響を形態的並びに機態的の両面より検討 した。

研究方法：実験材料は主として成熟家鬼の鼻粘膜お よび気管粘膜と慢性副鼻腔炎根治手術時に採取したヒ 卜上顎洞粘膜を用いた。機能的検索として線毛運動機 能を電気光学的手法 (既報) を用い測定し, 形態学的 検索として, 主として, 透過電子顕微鏡を用いて観察 した。

研究結果 : $10^{2} \sim 10^{5}$ 倍稀釈の高濃度の蟻酸と酢酸の 混合液では投与後直ちに線毛運動が停止し, 線毛上皮 細胞の障害も大きい。10 倍稀釈の濃度液では家鬼鼻 粘膜線毛運動は $2 \sim 3$ 分後に停止する。家鬼気管粘膜 線毛運動は鼻粘膜のそれよりも停止時間がやや延長す る。 $10^{7}$ 倍稀釈の濃度液では番粘膜も気管粘膜もとも に線毛運動は 1 過性に六進し, その後, やや低下する が停止することはない。しかし, 気管粘膜の方が兽粘 膜よりも影響が少ない。形態的には機能的変化を説明 しらる障害程度を示し, $10^{7}$ 倍稀釈液でも上皮細胞内 の細胞小器官にかなりの障害がみられた。ヒト副畺腔 粘膜でも，家鬼鼻粘膜と似た結果を示した。 
以上より，花粉中の有機酸そのものが上気道粘膜に 対して, かなりの刺激性を有し, 粘膜と気管粘膜に 対する障害に若干の程度の差があることを報告した。

\section{第16群 基礎一 5 \\ 座長 武田一雄 (阪医大耳鼻科)}

83）テトラヒドロフランの気道粘膜障害性に関する 実䄼的研究一楾毛運動機能と微細權造に及ぼす障 害一

○原田 博文, 中井 義明, 大橋 淑宏 桝谷 治彦, 大橋 一博 (阪市大耳番科) 片平 貞雄, 寺本 敬子, 堿口 俊一 （阪市大公衆衛生学）

テトラヒドロフランは, 古くから知られている有機 溶凨で塩化ビニル系樹脂の溶剂としてフィルム製造な どに広く使用されている。強い揮発性が知られてお り,これをとり扱う事業所では作業者に対する曝露も 無視できない。臨床的には, 噴覚障害, 畧炎, 副鼻腔 炎などが報告されているが，その気道粘膜に対する毒 性に関して実験的に検討されたことはなかったようで ある。我々は許容擞度である $200,1000 ， 5000 \mathrm{ppm}$ の テトラヒドロフランに曝露した鼻腔および気管粘膜の 形態的変化を電子顕微鏡により観察した。また線毛運 動機能を電気光学的手法を用いて直接的かつ定量的に 観察した。曝露期間が 1 日の場合, 許容浱度程度の曝 露では線毛運動にも障害は観察されなかったが, 曝露 が 1，3，12週間におよふと曝露莀度，期間に応じ て, 機能的にも形態学的にも種々の障害を認めた。

形態学的な主たる変化としては, (1)杯細胞の増加, (2)線毛細胞, 体内に大小種々の高電子密度 顆 粒の出 現，(3)線毛細胞の減少，(4)線毛数の減少，(5)複合線毛 の形成, (6)線毛膜の消失, (7)線毛細胞, 体内の小空胞 の増加や, 系粒体の膨化, 破壊などが観察された。ま た $5000 \mathrm{ppm}$ に 3 週間曝露された場合や，1000 ppm に 12週間曝露された場合の鼻粘膜ではさらに高度の障害 が観察され, 線毛細胞の脱落による基底細胞の露出,さ らに著しい場合には残存する基底細胞にも高度な破壊 像が観察された。また我々は, 気道以外の主要臟器の 光顕観察および血清化学的諸検查も施行したが, 著し い障害はいずれにも認めなかった。以上よりテトラヒ ドロフランが気道粘膜に対して障害性を有することは 確実であり, 許容漕度程度の曝露においても障害を認 めたことは今後の許容䀼度設定の根拠の 1 つして考 慮されるべきであろう。

質問：坂本 邦彦 (鹿大耳鼻科)

電気光学的方法の概略と分時打数の測定はどのよう にしているか。

忍答：大橋 淑宏 (阪市大耳番科)

薄片とした粘膜を位相差顕微鏡で観察する。粘膜の 折り目に出た線毛群にピンホール大の光源を当てる と, 線毛運動により, 光をさえぎる。装置下部に感光 板を置くと，光をさえぎる回数を測定することによ り, 運動数を測定しうる。分時運動数については, 3 秒間の値を積分する方法とオシログラフより計算する 方法の両者によって算出している。また，值の変動は 少ない。

\section{4）放射線照射の喉頭粘膜表面微細構造に及ぼす影 響に関する臨床的ならびに実験的研究 \\ ○谷口強, 三吉 康郎, 山本 真平 山田 清治, 福喜多啓三 (三重大耳畺科) 大山 勝 (鹿大耳鼻科)}

放射線照射の喉頭粘膜上皮におよぼす影響に関し て, 喉頭癌症例及びラット喉頭を用い表面微細構造の 变化を観察し，一部ラットにおいてはビタミンE (V. E）欠乏の放射線による細胞易傷性の問題について比 較検討した結果, 放射線病理ならびに喉頭癌の表面微 細構造に関して興味ある成績が得られたので報告し た。

(1)喉頭癌で術前照射 3000 4000 rad を受けた症例の 線毛細胞では線毛の膨化, ポリープ状変化, 水泡形 成, 膠着, 融合, 細短化, 脱落, さらに細胞脱落像 が,また無線毛細胞では,微䋐毛の膨化や融合, 細胞間 隙の離開, 細胞脱落後の痕跡像などの所見が観察され た。

(2)ラットに200 rad/日，総量 1000 rad および500 $\mathrm{rad} /$ 日，同しく1500 rad 照射した喉頭粘膜上皮ではヒトの それに近似した多彩な線毛細胞の傷害像が認められ た。しかし, 無線毛細胞では表面微細構造の変化は軽 微であった。また今回の $2000 \sim 3000 \mathrm{rad}$ 程度の照射実 験では, 総線量と細胞傷害との間に相関はみられなか った。

(3)V.E欠乏ラットで $500 \mathrm{rad} /$ 日，総線量2000 rad 照射 した喉頭粘膜上皮では, 対照例に比し線毛細胞と無線 毛細胞のいずれもその傷害筑囲, 傷害像が著明であっ た。このことは放射線が生物学的作用の一つとして生 体膜不飽和脂肪酸を過酸化脂質化し，一方ではV.Eに よってこの生体膜構造の変化を抑制できるということ が生化学的研究手法で立証されているが, V.E欠乏生 体では放射線照射によって形態学的に著しい細胞傷害 の生ずることが判明した。

(4)喉頭癌の SEM 像的特徵は, 細胞表面が円蓋状に 膨隆し表面に大小不同の粒状ないしは結節状, 不規則 な原形質突起がみられること, 細胞間結合の離開が著 しいこと, さらに EDX 分析により, 細胞表面に燐, 硫黄の両元素が多く検出されること等であった。

85）気管内捜管による残留酸化エチレンの生体障害 因子について 第 4 報 気管粘膜損伤の回復の経 時変化

○高島 征助 (クラレ中央研究所) 石井 宏典, 武田 一雄 (阪医大耳鼻科)

気管内㭔管する際, 気管内チューブに残留している 滅菌剤「酸化エチレン」(EOG) による気管粘膜の損 傷について検討する前段階として, モルモット（1群， 5 匹) に，それぞれ25，100，350，900ppm の EOG を含有する空気を 1 時間吸入させ, 直後, $7,14,28$, 42 日後に屠殺し気管を摘出し, 通常のグルタルアルテ ヒド〜オスミウム酸二重固定法で処理したのち, 走查 型電顕 (SEM) にて観察した。

観察結果を要約すると

1) ここで検討したEOGの淲度領域(25 900ppm) ではすべて線毛の尖端に水泡性形成物 (blebs formation）が認められる。25ppmの場合には 7 日，100ppm 
では14日ではこのような症例が軽減する傾向が認めら れる。しかし，350, $900 \mathrm{ppm}$ では 42 日後でもあまり 軽減しない。また, 水泡性形成物の大きさむ, EOG の濃度が増大するにしたがって増大する傾向があり， 形状も複雑になることも認められる。

2）吸入直後では低濃度領域においても線毛の膠着 が認められるが，1)の場合と同様に，25ppm では 7 日, $100 \mathrm{ppm}$ では 14日後には軽減する傾向が認められ る。しかし, 高溜度領域では䢧着はさらに進行し, 分

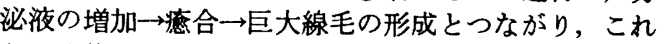
らの症状はここで検討した期間内では軽減しない。

3）線毛の配列の乱れの傾向の EOG 濃度への依存 性も, 先の1), 2)の場合とほほ同様であり, EOG の 鋠度が増大するにしたがって, 全体的に線毛の配列は randomになり, 個々の線毛も㹉じ曲り, 尖端部が屈 曲したものが数多く認められるよらになる。

86）気管開空後の文管に対する跉冷の影装

○坂本 伸雄, 海野 徳二, 川堀 真一 （旭川医大耳鼻科）

喉摘患者においては永久気管口を作製し，気管口か ら呼吸を行う。気管口からの呼吸は生理的にかなりの 変化があるものと思われる。旭川地区は冬期間にはか なり気温の下がる寒冷地区であるが, 我々は泠気を直 接気管口から吸った場合どのような変化があるか病理 学的に検討したので報告する。

方法：6 匹の犬を用い，5匹には気管開空を行い， 1 匹は処置せずコントロールとした。開空した犬は二 次的に声門の閉鎖手術を行ったが完全には開鎖されな かった。開空した 5 匹の5ち 1 匹は 2 冬を経た犬であ り, 参考のために観察した。術後冬期 $2 \sim 3$ 力月間屋 外にて飼育後気管を摘出し，仮に上・中・下と三区分 し，光顕・透過型および走査型電顕にて検討した。光 顕試料は $10 \%$ ホルマリン固定後パラフィン包埋し, H-E 染色を行った。電顕試料は $2 \%$ \%ルタールアルテ ヒド，2\%オスミウム酸固定，ウラニルアセラートお よびクエン酸鉛の二重染色を行った。走査型の試料は 臨界点乾燥後金の蒸着を行った。

結果および考按：今回の主な結果は以下の点に要約 できるものと思われる。1)線毛細胞の脱落，2)基底細 胞の増殖, 3)扁平上皮化生。

但し，これらの変化は三区分した気管の上部だけに 限られ，長期の寒冷刺激においても気道全体としてみ た場合その変化はごく限られた部位のみといえる。

経時的な変化や微小な変化等についても, 今回の結 果をもとに検討したい。

質問：戸川 清（秋田大耳鼻科）

寒冷に対する気管孔呼吸の不利を実証したが呼吸フ イルター装着の効果は? 私共は気管孔呼吸の 1 例 で, 気管壁軟骨露出, 結痂が持続した例に人工鼻 thermal humidifying filter を使用して好結果を得た。

応答：坂本 伸雄 (旭川医大耳鼻科)

実験条件を整えて再検討したい。

87）掣洷刺激によるラット気管支洗浄液中液性成分 の変動に関する研究

○門 政男, 満安 清孝, 大島 駿作 （京大結研内科 II）
Wistar 系雌ラット(150g 200g) に Hamburg II 型 契煙装圆を用いて，ハイライト煙を10，20，30，40分 間喫煙させ, 屠殺したのち 隇菌生食水 $2 \mathrm{ml}$ で気管支 を洗浄し, 洗浄液中の lysozyme, IgA, IgG，総蛋白 量を測定した。また，1 日15分，2週間連日喫煙させ たラットについても同様の方法で洗浄を行い，洗浄液 中の成分を測定した。総ての実験はラット5 匹を 1 群 として行い，気管支洗浄液は $4^{\circ} \mathrm{C}, 1500$ 回転で 15 分間 遠沈したのち, 上清を分離して測定した。洗浄液中の 各成分の総蛋白量との百分比を求めて経時的に比較す ると, lysozyme は喫煙前の 6.9 $0.2 \%$ から 10 分で $11.9 \pm 0.9 \%(\mathrm{P}<0.001), 20$ 分で $12.3 \pm 0.4 \%(\mathrm{P}<$ 0.001 ) と上昇し，30分では $7.9 \pm 1.0 \% ， 40$ 分では $3.4 \pm 0.2 \%$ と減少した。IgA は lysozyme と同様の 変動を示し, 盁煙前が $1.2 \pm 0.6 \%$ で 10分が $1.6 \pm 0.7$ $\%$ ，20分が $2.7 \pm 0.4 \%(\mathrm{P}<0.1)$ と上昇し, 30 分,

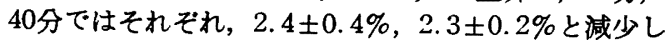
た。IgG は契煙前，10分，20分，30分がそれぞれ16.7 $\pm 1.9 \%, 14.0 \pm 3.8 \%, 16.8 \pm 2.8 \%, 15.6 \pm 3.5 \%$ で ほとんど変動せず，40分で27.8土2.6\% (P<0.01) と 急激な上䄯を示した。2 週間連日喫煙させたラットで

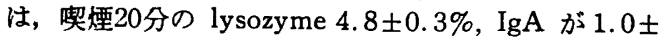
$0.3 \%, \mathrm{IgG}$ が $17.0 \pm 1.6 \%$ であり, 喫煙 20 分 1 回 のみのラットに比べて, lysozyme, IgA は低下して おり，IgGはほほ同じ值であった。

従って，喫煙によって気管支に刺激を加えると, 気 管支腺より lysozyme, IgA が分泌されて増加するが, 連日䒜煙により炎症が長期間継続すると, これらの分 泌が減少するものと考えられる。IgG は10分から30分 まで変動がなく，40分で急激に上㫒しており，また， 連日喫煙による変化も認められなかったため, 30分以 後に血液中より気管支内一の移行が急速に行われたと 考えられる。

犋問：武田一雄（阪医大耳鼻科）

常習的な喫煙でなく時たまの短時間喫煙は, lysozyme の分泌を促進し, 気道の感染に対して防蓹的に 働くと解釈してよいか。

応答：門 政男（京大結研内科 II）

喫煙で一時的には気管支分泌液中の IgA lysozyme は増えるが長期喫煙では分泌物中のそれらの成分は減 少し感染しやすくなるものと思5。IgA lysozyme に 補体が加われば E. coli の様な桿菌をも溶菌するとい う報告があり，一時的にせよ分泌物中のこれら成分の 増加が気道感染防禦に役立つものと思う。

\section{第17群 境界領域}

座長 河辺 義孝 (愛知がんセンター頭顥部)

88）失声についての心身医学的検期 (第一報) 高山乙彦, 飯田 信長 (日大板橋病院気食科)

○鴨下一郎, 山口 道也, 中谷 達広 佐野 茂男, 桂 載作, 岡安大仁 (日大第 1 内科)

目的：失声の発症に関与する心理的特性および失声 患者の性格傾向を明らかにしようとした。

方法：日本大学板橋病院気管食道科を受診した失声 
症の患者を, 同じく板橋病院心療内科を受診させ，9 種類の質問紙法心理テストを施行した。心理テストは CMI, KMI, SDS, MAS, INV, NCI, Egogram, EC L，Y.G 性格テストである。対象は，男 3 例，女 6 例 で年龄分布は17〜 74歳までである。

成績 : 1)CMI 深町判定法では I, II 領域 3 例，III, IV領域 6 例で神経症傾向を示す例が多かった。2) CM I の阿部自律神経失調傾向調查法では, 正常 3 例, 自 律神経失調傾向の認められる例は 6 例であり内 3 例は 神経症型であった。3)CMI のM〜R 項目ふよび強迫 ヒステリー, 恐怖項目の検討では, 不適応と強迫が多 く認められた。4)KMI では正常 4 例、心身症傾向 4 例, 神経症傾向 1 例であった。B項目の中ではZwang Unripe character が高い傾向であった。5)SDSによ るうつ傾向判定では 1 例のみうつ傾向を認めた。6)M A Sより有意の不安は 2 例にみられた。7)INV, NCI 両者による病前性格では epileptoid 傾向と nervous 傾向が多く認められた。

結論：9種類の質問紙法により失声患者の性格傾向 を検討し CMI, KMI, INV, NCI などの心理特性か ら強迫傾向が特徴として考えられた。質問紙法による 心理テストではヒステリー性格の患者が強迫の項目に 対して答えることもあり従来いわれているヒステリー の転換症状として失声を把えることも考えられた。

質問：石塚 洋一（東邦大耳鼻科）

最近学童にも心因性失声症が増えているが耳鼻科的 発声訓練を行っているか。

応答：高山 乙彦 (日大板橋病院気食科)

今回発表した症例は全例に声帯摩擦療法（直接喉頭 鏡先端で発声時に声帯を数回摩擦する) を行い効果は 劇的だった。

質問：進武幹 (佐賀医大耳鼻科)

1. 失声時の喉頭鏡所見は?

2. 心理検査を多く行っているが, 外来検查で最適 なものは?

応答：高山 乙彦

1) 軽、内筋麻疸像 4 例, 横筋麻㿉像 1 例, 呼吸時 の声帯の微細な瘵等像 2 例, 殆ど正常像 2 例であっ た。

応答：鴨下 一郎 (日大第 1 内科)

2) 心理テストは, cornell medical index, personality inventry, などが強迫，ヒステリーを把握する のには便利である。

\section{9）下咽頭異常感症例に見られる披裂輪状後部の浮 腫性腫脹}

$$
\begin{aligned}
& \text { ○山下 公一, 佐藤 喜一, 市川 朝也 } \\
& \text { 坪川 俊仁 (金医大耳鼻科) }
\end{aligned}
$$

はじめに：咽喉頭異常感は, 腫脹など明らかな病変 があるものを除き, 症候を説明するに十分な器質的病 変が認められないことが多く, 臨床上取报いに困惑す ることがある。このような症例に対して, 喉頭, 下咽 頭, 上咽頭, 食道の内視鏡的観察を行っているが, 梨状 陥凹とくに披裂䎾状後部に浮腫性腫脹を認める例が少 なくない,この場合上記の変化が咽喉頭とくに下咽頭 の異常感を起こす原因となると考えられるので検討を 行った。
症例の観察：下咽頭異常感を訴える 5 例である。年 龄は36〜59歳, 男 2 女 3 例, 発症から来院までの期間 は 1 力月から 3 年で,すでに他院を受診し異常なしと 言われた症例が 4 例あった。下咽頭食道透視では異常 なく，咽喉頭内視鏡で全例に披裂輪状後部にかなりの 浮腫性腫脹を認めた。また全例に面桃炎あるいは鼻咽 腔炎など咽頭の粘膜下リンパ組織の発赤を伴う炎症所 見が認められた。食道ファイバースコープは下咽頭食 道領城には上記以》の病的所見は認められなかった。 披裂輪状後部の生検所見はリンパ管の著明な拡大と一 部に間質の線維性増殖などをみ，炎症細胞浸潤はほと んど認めなかった。部位により粘膜下に杯中心を含む リンパ組織と一部には壊死巣を含ら小膿瘍などを認め た。

まとめ：披裂輪状後部は声門の開閉，喉頭の上下運 動などで常時はげしい伸展と圧迫を受け，さらに外来 の刺激とくにくり返す炎症にさらされる部位でありま た輪状軟骨と頸椎にはさまれていることから，粘膜下 組織の腫脹が異常感の原因となり得ると考えられ，綿 棒でこの部分が異常感のある部分と確認できる症例も あった。対策は周囲の北桃組織の消炎療法と，食道内 視鏡を含めた局所の詳細な観察によって腫瘍などとの 鑑別を行うことである。

90）咽喉頭異常感と喉頭病変

石塚 洋一, 浦野 光永, 传竹 敬一 小松崎 篤 (東邦大耳睤科)

咽喉頭異常感を訴えて来院する患者は増加の傾向に あり,その訴えは複雑で症例により詳細な検索が必要 となる。

昨年の気管食道科学会で，咽喉頭異常感を訴えて来 院する患者の中でも仮声带腫脹を認めた患者を報告し たが，今回同様の主訴で来院した患者の中で，喉頭に 器質的病変を認めたものを検討し, 各種喉頭病変と咽 喉頭異常感の違いも検討したので報告する。

症例 1 は66歳男子で, 左側頡下部付近に活液や食物 の噁下時に魚の骨がささっている様な咽喉頭異常感を 訴えて来院した。左側喉頭蓋喉頭面の扁平上皮癌であ った。症例 2 は60歳男子で右側喉頭蓋扁平上皮癌を認 めた。症例 3 は左側仮声帯より発生したと思われる扁 平上皮癌であった。症例 4 は右側仮声帯前方に血腫様 の病変があり, 病理検査で浮腫性変化との結果を得 た。症例 5 , 症例 6 は喉頭蓋のう腫症例で, 症例 7 は 気管壁に Falte 様突出を認めた。今回発表した 症 例 のように咽喉頭異常感を主訴として来院した患者の中 にも喉頭に病変を認める症例が多く含まれていること がわかった。我々の経験した症例をまとめると，声門 上癌, 喉頭のう腫, 喉頭炎, 仮声带腫瘍, 声帯ポリー プ, 声帯結節, 喉頭麻㾇, 喉頭異物, と様々な疾患に わたっている。訴える咽喉頭異常感がどの部位かとい うことは重要な問題となってくる。すなわち, 䫟下部 付近の訴えは喉頭蓋, 甲状軟骨の上部外側は仮声帯, 甲状㳄骨部付近は声帯, 披裂部, 甲状㳄骨下方の訴え は下咽頭下部, 気管, 食道入口部の異常を示すことが 多い。

以上より咽喉頭異常感は, どのような訴えがどのよ らな部位に存在するのか, 背下との関連性はどうか, 
訴えが左右に偏していないかなどに注意し，喉頭所見 を正碓に把握しなければならないと考える。

追加：㴰野 蘋一（聖路加国際病院気食科）

咽喉頭異常感症の診断には, 内視鏡下に局所見を確 認する必要があるが, 私は喉頭フフイバースコープで 直達鏡下の検査を外来で行っている。ウェルチの充電 ハンドルを装着できる喉頭ファイバースコープは病室 や往診先での検査にも便利である。

\section{1）咽唉頭異常感を主訴として耳年科を受診した精} 神疾患 2 症例の検討

○三好 彰, 河本 和友 (東北大耳番科)

咽喉頭異常感を主訴として耳悬科を受診する症例の 中には様々の非器質的疾患, 特に精神疾患が含まれて いる。

現在までに我々が経験した咽喉頭異常感症症例のう

ち精神疾患によるものとして, 今回は depression の

一症例, Cenesthopathie の一症例につき報告した。

症例 135 藏 女性 Depression

咽喉頭異常感にて 1 年前から某耳悬科医に通院して

いたが精神性・心因性の精查を目的として，当科紹介 となる。

当科にて施行した梯々の心理テスト並びに抗らつ剤 に対する反応から，本症例は depression と診断され 薬物㫫法が施行された。

しかし本症例は環境的な問題等もあり後に強力な精 神療法の併用が必要となったが何とか軽快を見ること ができ，現在外来通院にて経過観察中である。

症例 224 歳 男性 Cenesthopathie

'80年 7 月初め頃より「食物がのどに引っかかって 上下する感し」を主訴として某耳粤科医を受診, 心気 的な訴えが多い為某医を経て当院精神科へ入院とな る。

精神科主治医の依頼で耳鼻科的に精査, 器質的には 全く異常のないことをくり返し本人に説明し現在経過 観察中である。

耳鼻科医は一般に必ずしも精神科的な専門知識を有 している場合ばかりでもない為, 精神疾患によって生 ずる咽喉頭異常感に対し十分な診断・治療が行われて いない可能性がある。しかし，ここに報告した如く現 実に精神疾患症例が耳勫科外来を受診する以上診療に

当っては細心の注意をはらう必要があろう。

質問：日野原 正 (獨協医大気食科)

症例 1 は masked depression case ではなかった か。何日目にそれぞれ精神科に依頼したか。精神科依 頼への苦心は?

忍答：三好彰 (東北大耳鼻科)

Masked depression Łいうには, 精神症状が強い ように思う。

症例 1 は, 精神科紹介が患者にとって不利益になる と考えられ，精神科医に liaison psychiatry を依頼し た。

症例 2 は, 精神科で器質的病変が無いことを確認 し, 共に精神療法に当ってくれ, という依頼があった 為, 当科にて加療した症例である。

92）食道入口部の臨床解剖学的镜察 ○進 武幹（佐賀医大耳鼻科）
平野 実, 吉田 義一, 大久保 洋 江崎 修市, 栗田茂二朗, 平出 芳生 宫崎 俊巳 (久大耳鼻科)

咽頭と食道の境界部を臨床的に食道入口部と呼称し ている。この部位には輪状咽喉筋および頸部食道筋が 存在し, 狭䆨部位として重要な部位といわれている。 従来より，輪状咽頭筋を中心として上下に脆弱部が存 在し, Killian の欠損部, Laimer の三角部といわれ る。この部位は, 食道鏡施行時に穿孔をきたしたり, 憩室の発生部位として知られている。

本研究は食道入口部の構造を再検討し臨床的問題点 を明らかにすることを目的とした。

研究材料：人屍体より喉頭を含め, 甲状咽頭筋，輪 状咽頭筋，頸部食道管を一塊として摘出し大切片を作 成し用いた。

研究結果：矢状断面における所見では，咽頭および 食道の粘膜は重層扁平上皮でおおわれ，境界部に明確 な差はみられない。それぞれの粘膜から笳層までの厚 さをみると食道側の方が薄く, 咽頭側の方が厚い。そ の境界部の状態は，咽頭側の方から漸次薄くなってい る。いずれの側においても筋層結合織の久如した部位 はみられていない。筋の走行を食道側よりみると食道 の内輪笳より咽頭側へ移行すると漸次斜走する筋層へ と移行する。

輪状軟骨下縁における横断面では食道前壁と輪状軟 骨後面の間に筋層が存在し食道筇と思われる。また, 輪状軽骨に近い部位に外縦筇がみられ，食道粘膜寄り に内輪觔がみられる。また,この部位に粘液腺が散見 され，阽液を分泌していると思われる。食道入口部の 後壁は輪状咽頭筋の厚い層により囲ほれている。

以上の結果から，輪状咽頭筋を中心とした上下に筋 層結合織の欠損部はみられていない。したがって臨床 的に脆弱部といわれる部位は筋の欠損ではなく, 食道 入口部の筋層の厚み, あるいは筋線維の走行の具合で 脆弱になっているのではないかと推測される。また個 人差あるいは人種差によると考えられる。

質問：丘村 熙(愛媛大耳鼻科) は?

(1)Pouch, 憩室は高齡者に多い。摘出標本の年龄

(2)Pouch，憩室の発生要因として，筋収縮の 異常と 咽頭圧が問題とされている。形態学的に筋欠損はなく ても, 筋収縮時には欠損部が露見されてくる可能性は ないか。

态答：進武幹 (佐賀医大耳鼾科)

(1)年齢は女性の 1 例のみ37歳で, 残りはすべて50歳 以上の高齸者であった。

(2)員室の発生要因は，例外的に筋の欠損部などによ るものが推定される。生理学的な筋の収縮との関係は むずかしい問題である。

93）食道入口部についての検討

○白幡 雄一, 渡辺健一郎, 瀧野 賢一 （聖路加国際病院耳鼻科・気食科）

診断的食道鏡検査に合併する食道穿孔は食道入口部 に多発する。その原因は限られた鏡管内の視野で，狭 い管腔に向けて鏡管を押し進めることによる misdirection にあると思われ内視鏡的立場から食道入口部に 
検討を加えた。

新解人屍体5体を用いて食道入口部の解剖を行い, 能 肉の走向を確認した。また食道鏡挿入に際し最初に抵 抗を受ける輪状咽頭筋の上縁; 輪状咽頭筋一甲状咽頭 筋接合部の組織像を連続切片を作って観察した。症例 のなかに, 正中で vertical section した slice に Killian's dehiscense といわれる筋肉の欠如を認めた。筋 肉の途絶がみられ結合織のみにて形成された後壁は外 力に対して穿孔の危険が高、。食道鏡の㨂入に際しこ の部では後壁に無理な圧力をかけてはならない。

この解剖的脆弱部位である輪状咽頭筋上縁の臨床解 剖的名称は必ずしも統一されていない。Lannier Hackermann 部とか, Laimer の三角部とかいわれる が, 正しくは Lannier は Laimer の間違いで, 両者 は輪状咽頭筋下方の三角部をさすものと思われ，この 部位を臨床的に Killian の久損部と呼称するのが適当 と考えた。

食道入口部では輪状軟骨が蕜下に際し上下に運動 し，殊に老人では第 6 颈椎を中心とした Spondlyosis が多くみられる。食道鏡検査に際し，適切な体位をと らないと顠椎の前方隆起が強まり，鏡管と頸椎との間 で後壁粘膜を損傷することにもなる。

輸状咽頭筋の過緊張による抵抗の增大も食道穿孔を 起こし易い因子の一つである。私共は食道鏡㨂入時の 輪状咽頭筋の筋電図を記録した。正常噮下と比較し, 插入の前と後で筋肉の緊張が高まり, 永く持続するこ とが判明した。䇗肉の祭張を解くために, 充分被権者 をリラックスさせる必要がある。

以上食道入口部の解剖的, 生理的特殊性を考虑し, 危険なく食道鏡検査を行う要点について述べた。

質問：遠藤 光夫 (女医大消化器病センター外科)

(1)臲弱部の呼称, とくに上脆弱部の呼び方につ $\tau$.

(2)Zenker 想室の大きさと愁訴との関保は?

応答：瀧野 堅一(聖路加国際病院気食科)

(1)I_annier Haeckerman's space と称される部位 は, Lannier が Laimer の誤記と思われ Killianの 眊弱部と称した方がよいと思う。

(2)食道蒩室例の主訴は，食物が食道の入口あたりに 何んとなく残る感がするということであった。

\section{第18群 内視鏡一 1}

座長 斎藤 成司 (慶大耳鼻科)

94）幼小児用 Ventilating Laryngoscope ○田村 京子, 稲見 浩三, 山本 泰久 神谷 道子, 松原啓, 藤井 之正 清水一彦, 中野 尚美, 黒須 吉夫 （東邦大麻酔科）

術野と麻酔実施野が同一部位となる全麻下咽喉頭検 查は, 術者はもとより我々麻醉科医にとっても深、関 心を持たさるを得ない。対象患者が成人の場合, 細目 の気管チューブ㨂入下（黒須，1964），特製気管内チ ュープの使用 (Carden, 1974) や Foley のカテーテ ル利用法 (Lewis, 1977) など各種工夫がこらされて いる。反面, 解剖・生理学的に種々制約のある幼小児 の場合, なお一啳の工夫・改善が必要と思われる。従
来, われわれは幼小归咽喉頭検査には自発呼吸下検査 可能なエーテル開放点滴法を籠用してきたが，導入・ 維持・覚醒に高度の熟練を要するなど一般的でないの で, Oulton (1971) らの報告にヒントを得 て, 今回 幼小児用 ventilating laryngoscope を考案, 試作, 臨床応用を試みた。

幼小児用ミラー型喉頭鏡ブレードに実験結果より適 正と考えられる内径 $3 \mathrm{~mm}$ の jet-injection チューブ を装着, Saunders (1967) らの jet-injection の原理 を応用, 送気源としてこれに Nuffield 200 Ventilator を接続使用した。臨床例は 4 力月男児より 6 歳児に至 る Risk 1 の一般外科手術対象患児23例に本法を用 いた。幼小児における jet-injector technique の応用 は, 換気状況のモニターの困難性及び偶発的過剩過圧 の危険性があるので，あらかしめ3歳児を想定した換 気諸条件下で本法を施行, その妥当性化ついては, 各 種 vital signs, ECG に加えて三栄測器社製患者監視 装置 2205B型による呼吸曲線と血液ガス值の測定, な らびに Datex Normocap による呼気終末 $\mathrm{CO}_{2}$ 渡度 を測定記録したが全例に概ね満足すべき結果を得た。 今回経験した Nuffield 200 Ventilator の機能上の制 約から現状では必すしも最適の換気条件を設定し得な かったが, 症例ごとの適切な喉頭展開位置, 換気条件 が得られれば，本法は狭小な術野の幼小児咽喉頭検查 にはなはだ有用な一方法であるといえよう。

95) Ventilation Bronchoscopy を行った症例の検 討

$$
\text { ○石橋 康, 玉虫昇, 松井道夫 }
$$$$
\text { （神奈川こども医療センター耳粤科） }
$$

過去 11 年間に神奈川県立こども医療センターで ventilation bronchoscopy を行った症例は95例でこ れら症例について検討したので報告する。

検査を行った症例の年齢は 1 カ月より13藏であり, その内訳は 3 力月以下 11 例, $4 \sim 6$ 力月11例, 7 力月 $\sim 1$ 歳18例, 1 歳代29例, 2 歳代12例, $3 \sim 6$ 歳 6 例, 7 歳以上は 8 例で男児65例, 女児30例であった。

対象は気管気管支異物が疑われたもの40例, 呼吸障 害の検索 51 例, 喀痰および血痰の原因検索が各々 3 例, 1 例であった。

結果は異物が碓認されたもの35例, 異物が疑われ異 物のなかったものが 5 例あった。その他気管狭窄症 5 例( 552 例血管輪), 気管 - 気管支炎 3 例, 気管切開 孔部の肉来症が 3 例あった。1 例では右気管支よりの 出血が確認できた。2 例は両側気管支より膿汁の排出 がみられ気管支㹡張症が疑われた。41例は気管・気管 支に病変は認められなかった。

検查施行後に喘鳴などの呼吸障害が増強したものが 少数例にみられたが気管切開や気管内拽管のような特 別な気道確保を要しないでまもなく枝快した。その他 合併症はみられなかった。

Ventilation bronchoscopy は麻酔医の協力のもと では安全に行えるので気管・気管支異物が疑われる場 合や乳幼児の呼吸困難の原因検索には積極的に行うべ きと考える。

96）曲した喉頭直達鏡による喉頭手術の試み ○笠 誠一, 小宮山荘太郎, 渡辺宏 